УДК $553.8+550.42$

\title{
ФИЗИКО-ХИМИЧЕСКИЕ ОСОБЕННОСТИ ФЛЮИДОВ, СФОРМИРОВАВШИХ АПОГИПЕРБАЗИТОВЫЕ И АПОКАРБОНАТНЫЕ НЕФРИТЫ
}

\author{
Филиппова Анастасия Алексеевна', \\ a.filippova@igc.irk.ru
}

\author{
Мехоношин Алексей Сергеевич1,2, \\ mekhonos@igc.irk.ru
}

\author{
Бычинский Валерий Алексеевич1, \\ val@igc.irk.ru
}

\author{
Чудненко Константин Вадимович1, \\ chud@igc.irk.ru \\ 1 Институт геохимии им. А.П. Виноградова СО РАН, \\ Россия, 664033, г. Иркутск, а/я 9, ул. Фаворского, 1 А. \\ 2 Иркутский национальный исследовательский технический университет, \\ Россия, 664074, г. Иркутск, ул. Лермонтова, 83.
}

\begin{abstract}
Актуальность. В наиболее крупной в России Сибирской нефритоносной провинции обнаружены месторождения двух формационных типов - апогипербазитовый и апокарбонатный. Их тела формируются на контактах серпентинизированных пород и доломитовых мраморов с алюмосиликатными породами. Актуальность работы определяется тем, что установлены факторы, контролирующие единообразие минералогических типов нефритов различного генезиса, - состав гидротермального раствора и Р-Т условия процесса.

Цель. Критическое обобщение мирового материала по геохимии и петрологии нефритов позволяет достичь основной цели работы - подготовить исходные данные для формирования модели, адекватно описывающей особенности физикохимических процессов образования как апокарбонатных, так и апогипербазитовых нефритов.

объекты: Кавоктинское месторождение апокарбонатного нефрита и Оспинское месторождение апогипербазитового нефppuma.

Методы. Представленный химический состав пород определялся фотометрическим, атомно-абсорбционным, потенциометрическим и пламенно-фоотометрическим методами, содержание микроэлементов - методом масс-спектрометрии с индуктивно связанной плазмой. Изотопные составы кислорода и углерода проанализированы методом лазерного фрторирования, а углерод и кислород в карбонатах - по методике разложения ортосросфорной кислотой. Изотопный состав водорода в гидроксилсодержащих минералах определен по методу Vennemann, O'Neil.

Результаты. Мировые данные по геохимии и петрологии нефритов позволили установить, что апогипербазитовые нефриты формировались под воздействием магматических и метаморфических вод из серпентинитов, в апокарбонатных проявлениях нефрита фрюид представляет собой метеорные воды, насыщенные углекислотой, образующейся при декарбонатизации доломита. Рассмотрена последовательность образования минеральных парагенезисов при развитии метасоматической зональности на контакте пород различного состава. По минеральному парагенезису апокарбонатный нефрит относится к низкотемпературной фации магнезиальных скарнов $\left(350-400{ }^{\circ} \mathrm{C}\right)$. В результате формируется следующая метасоматическая зональность: доломитовый мрамор - кальцитовый мрамор с нефритом - тремолитовый скарн - пироксен амфибол - клиноцоизитовый скарн - амфиболиты. Месторождения апогипербазитового нефрита имеют иную метасоматическую зональность: микроантигоритовый серпентинит - тремолитит - нефрит - тремолитит - квари-диопсидклиноцоизитовый родингит - цоизит-амфиболовая порода. Температура меняется в интервале $300-450{ }^{\circ} \mathrm{C}$, давление 2000 3000 бар. Эти данные в сочетании с химическим и изотопным составом позволяют построить модель, адекватно описывающую особенности физико-химических процессов образования как апокарбонатных, так и апогипербазитовых нефрритов. Следовательно, единообразие минералогических типов нефритов различного генезиса определяется составом гидротермального раствора и Р-Т условиями процесса.
\end{abstract}

\section{Ключевые слова:}

Нефрит, геохимия, изотопы, физико-химические условия образования, Восточная Сибирь.

\section{Введение}

Геологические, петрографические, петрохимические и археологические [1-4] исследования апогипербазитовых и апокарбонатных метасоматитов, включающих жадеиты и нефриты, позволили разработать общую теорию их генезиса и на её основе построить геолого-геохимические модели образования нефрита [5]. Однако источник флюида, как и основные термодинамические и кинетические параметры нефритообразования (температура, давление, соотношение флюид/порода, относительное время процесса), не был однозначно установлен.

Рассматривались равновесные термодинамические модели метасоматических процессов без привлечения кинетических и динамических параметров [6]. Исследовалось взаимодействие гипотетического флюида с исходной породой. Воздействие контактирующих подстилающей и перекрывающей пород не учитыва- 
лось. Это не позволило точно реконструировать физико-химические условия формирования существующей метасоматической зональности. Полученные результаты были лишь приближением к реальным процессам минералообразования. Конструктивного решения задачи расчета минеральных парагенезисов совокупности взаимодействующих систем ни в отечественной, ни в зарубежной практике получено не было. Основными проблемами построения современных физико-химических моделей являются: недостаток исходных данных по термодинамическим свойствам минералов, компонентов гидротермальных растворов, газов, а также отсутствие кинетической постановки, отражающей специфику метасоматических процессов Под кинетической постановкой понимается не только масса и объемы взаимодействующих пород, но время и режим воздействия флюида на породы. Эти наиболее важные параметры метасоматоза, как и источник флюида, в моделях не учитывались.

В данной статье обозначим факторы, которые позволяют в конструкции физико-химической модели описать термодинамические особенности минеральных систем, существующих в условиях метастабильного равновесия. Для этого необходимо решить следующие задачи: определить минеральные составы взаимодействующих пород, учитывающие элементыпримеси, компонентный состав гидротермального раствора и газовой фазы; установить размеры и массы взаимодействующих тел и режим обмена веществом между ними; определить интервалы температур, давлений и время, за которое возможно формирование полной метасоматической зональности. Только после решения этих задач будет возможна физикохимическая интерпретация основных особенностей процесса образования нефрита, соответствующая термодинамическим параметрам, что гарантирует сходимость численных решений с экспериментальными и природными наблюдениями.

Химический состав пород, используемый в расчетах, определялся фотометрическим, атомно-абсорбционным, потенциометрическим и пламенно-фотометрическим методами, содержание микроэлементов - методом массспектрометрии с индуктивно связанной плазмой. Изотопные составы кислорода и углерода проанализированы методом лазерного фторирования, а углерод и кислород в карбонатах - по методике разложения ортофосфорной кислотой [1]. Изотопный состав водорода в гидроксилсодержащих минералах определен по методу Vennemann, O’Neil [2].

Поэтому на первом этапе исследования обозначим факторы, позволяющие в конструкции физикохимической модели точно описать термодинамические особенности минеральных систем, существующих в условиях метастабильного равновесия. Вопервых, это минеральные составы взаимодействующих пород, учитывающие элементы-примеси, компонентный состав гидротермального раствора и газовой фазы. Во-вторых, это размеры и масса взаимодействующих тел и режим обмена веществом между ними. В-третьих, это температура, давление и время, необходимое для формирования полной метасомати- ческой зональности. В результате исследуемые объекты получат физико-химическую интерпретацию, соответствующую термодинамическим параметрам метасоматических процессов.

Подобные принципы позволяют создать термодинамические модели с более сложной микро- и макроструктурой по сравнению с задачами, которые решались в моделировании до сих пор. Возможен расчет равновесного состава систем, включающих твердые фазы, газовые смеси и гидротермальный флюид [7].

\section{Минералогические структурные, химические}

\section{и физические особенности нефритов}

Апосерпентинитовые и апокарбонатные типы нефрита формируются на контакте магнезиальносиликатных (магнезиально-карбонатных) и алюмосиликатных пород, под воздействием гидротермальных растворов, приносящих химические элементы из глубинных очагов или контактирующих пород [8]. Формирование спутано-волокнистой структуры нефрита обусловлено стрессовым давлением [9, 10].

Апогипербазитовые нефриты формировались под воздействием метаморфических растворов, апокарбонатные нефриты - под воздействием флюида, возникающего из метеорных вод, насыщенных углекислотой, образующейся при декарбонатизации доломита [10].

По минеральному парагенезису апокарбонатный нефрит относится к низкотемпературной $\left(350-400{ }^{\circ} \mathrm{C}\right)$ фации магнезиальных скарнов [8]. Нефрит образуется в мелких ксенолитах доломитовых мраморов среди гранитов. Зоны тектонических нарушений и трещиноватости являются путями проникновения гидротермально-метасоматических растворов. В результате формируется следующая метасоматическая зональность: доломитовый мрамор - форстерит-кальцитдиопсидовый скарн - нефритсодержащий кальцит тремолитовый скарн - пироксен - амфибол - клиноцоизитовый скарн - амфиболиты.

Разнообразие окраски апокарбонатных нефритов от зеленовато-голубой до желтовато-кофейной, в отличие от апогипербазитовых разностей, имеющих зеленую окраску различной интенсивности, связано с особенностями химического состава. Содержание $\mathrm{Fe}^{2+}$ в апокарбонатных нефритах 0,15-1,82 мас. \%, в апогипербазитовых разностях - 2,58-4,38 мас. \%. Концентрация $\mathrm{Cr}$ и $\mathrm{Ni}$ в апогипербазитовых нефритах на два порядка выше, чем в апокарбонатных. Другой особенностью апокарбонатных нефритов является высокое содержание фтора (до 1 \%).

Минеральные составы апогипербазитового и апокарбонатного нефрита отличаются. Если для апогипербазитовых разностей характерны серпентин, тальк, диопсид, пренит, магнезит, эпидот, цоизит, гранат, тремолит, сфен, магнетит, хромшпинелид, в качестве примеси апатит, хлориты, сульфиды и гидроокислы железа. В апокарбонатных нефритах присутствуют кальцит, доломит, тремолит [кварц, серпентин, диопсид, тальк, реже флюорит.

Прежде чем приступить к созданию полноценной модели образования нефрита, необходимо определить, что известно, а что не известно о его образовании. 
Преимущество физико-химического моделирования по сравнению с существующими методами построения P-T и Eh-pH диаграмм устойчивости минеральных парагенезисов и водных комплексов или описания геологических структур состоит в более глубоком изучении закономерностей изменения минеральных парагенезисов в зависимости от степени протекания процесса. На каждом шаге фиксируется изменение химического состава новообразованных твердых фаз, концентраций и химических потенциалов. При этом важно, что в численных экспериментах открываются сложные химические взаимоотношения, которые не обнаруживаются при визуальном наблюдении или в экспериментах с элементарными системами.

\section{Кавоктинское месторождение}

Кавоктинское месторождение расположено в верховьях р. Кавокты. Доминирующее распространение име- ют в различной степени гранитизированные метапесчаники, кристаллические сланцы, образующие среди гранитоидов различные по размерам ксенолиты. Более широко развиты амфиболовые и пироксен-амфиболовые кристаллические сланцы. Доломитовые мраморы образуют в гнейсах и сланцах небольшие по мощности прерывистые прослои и линзы, резко уступающие по размерам таковым других месторождений. Минеральный состав пород месторождения приведен в табл. 1.

Апокарбонатные месторождения нефрита формируются в зонах развитого кислого магматизма с преобладанием субщелочных калиево-натриевых высокоглиноземистых гранитоидов, контактирующих с ксенолитами доломитовых мраморов, по которым в процессе инфильтрационно-диффузионного кремниевого метасоматоза формируются залежи апокарбонатного нефрита (рис. 1).

Таблица 1. Минеральный состав нефритсодержаших метасоматических колонок Ковоктинского месторождения

Table 1. Mineral composition of jade metasomatic columns of Kovoktinskoe deposite

\begin{tabular}{|c|c|c|c|c|c|}
\hline & & & Кварц/Quartz & & \\
\hline & & & Биотит/Biotite & $\mathrm{KMg}_{3} \mathrm{Fe}_{3} \mathrm{~A}$ & $\mathrm{Si}_{3} \mathrm{O}_{10} \mathrm{OH}_{2} \mathrm{~F}_{2}$ \\
\hline 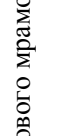 & 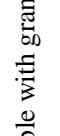 & $\begin{array}{c}\text { Гранитоиды } \\
\text { Granitoids }\end{array}$ & $\begin{array}{c}\text { Полевой шпат } \\
\text { Feldspar }\end{array}$ & $\begin{array}{c}\text { Микроклин } \\
\text { Microcline } \\
\text { Андезин } \\
\text { Andesine }\end{array}$ & $\begin{array}{c}\mathrm{KAlSi}_{3} \mathrm{O}_{8} \\
\mathrm{NaCaSiAl}_{4} \mathrm{O}_{8}\end{array}$ \\
\hline & 营 & & Роговая обманка Hornblende & $\mathrm{Ca}_{2} \mathrm{Mg}_{5} \mathrm{Fe}_{5} \mathrm{~A}$ & $\mathrm{Al}_{8} \mathrm{Si}_{8} \mathrm{O}_{22} \mathrm{OH}_{2}$ \\
\hline & J & & Апатит/Apatite & $\mathrm{Ca}_{5} \mathrm{PC}$ & ${ }_{2} \mathrm{FOHCl}$ \\
\hline & 光 & & Cфен/Sphen & $\mathrm{Ca}^{\prime}$ & $\mathrm{SiO}_{5}$ \\
\hline$\stackrel{g}{\mathscr{E}}$ & $\frac{0}{0}$ & & Кальцит/Calcite & & $\mathrm{CO}_{3}$ \\
\hline 窇 & 8 & Мрамор & Доломит/Dolomite & $\mathrm{CaM}$ & $\left(\mathrm{CO}_{3}\right)_{2}$ \\
\hline 范 & \pm & Marble & Форстерит/Forsterite & & $\mathrm{SiO}_{4}$ \\
\hline 光 & 垔 & & Апатит/Apatite & $\mathrm{Ca}_{5} \mathrm{PC}$ & $\mathrm{FOHCl}$ \\
\hline 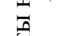 & 8 & & Форстерит/Forsterite & & $\mathrm{SiO}_{4}$ \\
\hline $\mathrm{E}$ & $\Xi$ & & Кальцит/Calcite & & $\mathrm{CO}_{3}$ \\
\hline 항 & $\frac{\pi}{\pi}$ & Forsterite-calcite-diopside skarn & Диопсид/Diopside & $\mathrm{CaN}$ & $\mathrm{Si}_{2} \mathrm{O}_{6}$ \\
\hline$\underbrace{\pi}_{0}$ & 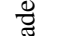 & & Тремолит/Tremolite & $\mathrm{Ca}_{2} \mathrm{Mg}$ & $\mathrm{i}_{8} \mathrm{O}_{22} \mathrm{OH}_{2}$ \\
\hline 量 & $\stackrel{\underline{\omega}}{0}$ & & Доломит/Dolomite & $\mathrm{CaM}$ & $\left(\mathrm{CO}_{3}\right)_{2}$ \\
\hline 苋 & क्ञ & Нефрит & Кальцит/Calcite & & $\mathrm{CO}_{3}$ \\
\hline 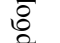 & 竘 & Nephritis & Тремолит/Tremolite & $\mathrm{Ca}_{2} \mathrm{Mg}_{5}$ & ${ }_{8} \mathrm{O}_{22}(\mathrm{OH})_{2}$ \\
\hline 害 & ర్ & & Кварц/Quartz & & $\overline{\mathrm{O}_{2}}$ \\
\hline & $\overline{4}$ & $\begin{array}{l}\text { 1ремолит } \\
\text { Tremolite }\end{array}$ & Тремолит/Tremolite & $\mathrm{Ca}_{2} \mathrm{Mg}$ & $\mathrm{i}_{8} \mathrm{O}_{22} \mathrm{OH}_{2}$ \\
\hline & & & Тальк/Talc & $\mathrm{Mg}_{3} \mathrm{~S}$ & $\mathrm{O}_{10} \mathrm{OH}_{2}$ \\
\hline
\end{tabular}

Фактором, предопределяющим процесс апокарбонатного нефритообразования, является существенно доломитовый состав исходных пород [11]. Доломитовые мраморы имеют средне-крупнозернистую структуру и массивную текстуру. Их минеральный состав представлен доломитом (80-90\%), кальцитом (0$10 \%)$, форстеритом (0-20\%). Между доломитовыми мраморами и гнейсами встречаются удлиненные, согласно общему простиранию, прослои и линзы кварцполевошпат-амфиболовых кристаллических сланцев.

Процессы метасоматического преобразования пород, связанные с постмагматическим этапом становления гранитоидов проявлены локально в зонах оперяющих тектонических нарушений либо приурочены к тектонически осложненным контактам пород [12]. Интенсивно они проявились в замке антиклинальной складки, где на контакте доломитовых мраморов с алюмосиликатными породами происходило образование нефритсодержащих скарнов.
В зависимости от литологических закономерностей пространственного размещения скарнов выделяются следующие типы залежей: 1) приуроченные к контакту доломитовых мраморов и гранитов; 2) приуроченные к контакту доломитовых мраморов и полевошпат-кварц-амфиболовых кристаллических сланцев; 3) залегающие в теле мраморов вне видимой связи с алюмосиликатными породами.

Состав аподоломитовых скарнов и характер распространения в них обособлений тонковолокнистого тремолита, представляющего собой нефрит, во всех типах залежей сходен, однако их мощности в каждом из трех случаев различны. Наиболее значительных размеров (до 2-2,5, реже до 3 м) достигает экзоскарновые зоны второго и третьего типов залежей. Наименьшие значения (0,5-1 м) характерны для метасоматитов гранитных контактов. [13]. Минеральный состав экзоскарновых зон представлен кальцит-тремолитовой породой с варьирующим соотношением минералов. 

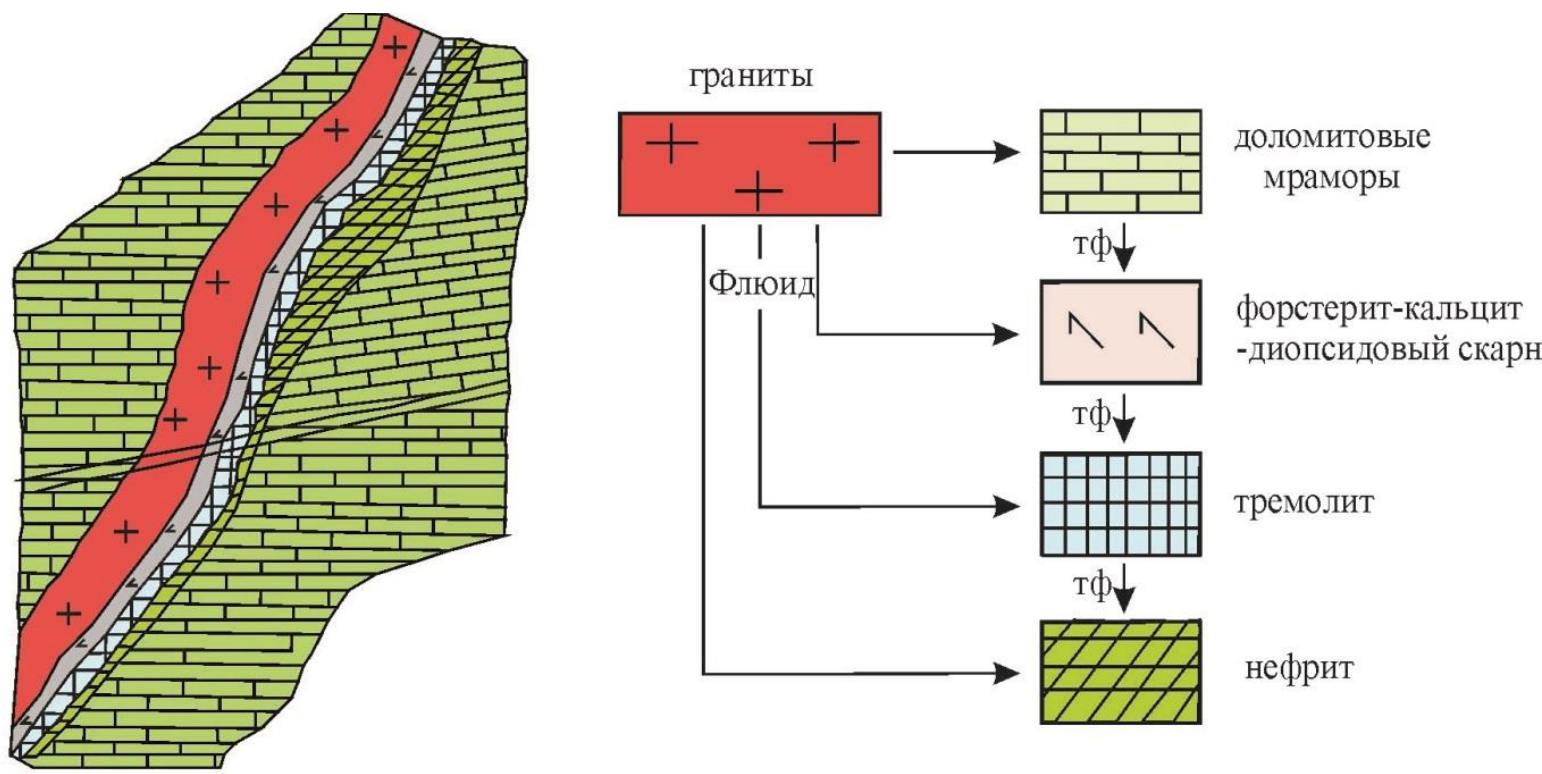

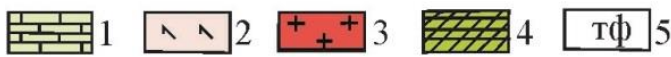

Рис. 1. Схема нефритовой жилы на контакте доломитовых мраморов с метаморфизованными гранитами и блоксхема последовательных стадий образования нефрита [11]: 1 - доломитовые мраморы; 2 - скарны;; 3 - граниты; ; - нефриты, 5 - твердые фазы

Fig. 1. Scheme of the jade vein on contact of dolomite marbles with metamorphized granites and flowchart of linear stages of jade formation [11]: 1 -dolomite marbles; 2 -scarns; 3 -granites; 4 -jades; 5 -solids

Гидротермально-метасоматическая деятельность на контактах доломитовых мраморов с алюмосиликатными породами, главным образом с амфиболитами, и привела к возникновению нефритсодержащих скарновых залежей. Единообразная зональность скарновых тел иногда нарушается наличием реликтовых участков, сложенных метасоматически измененными габброидами [14].

Таким образом, установлены основные особенности процессов формирования месторождений апокарбонатного нефрита. Преобладающий генетический тип гранитоидов - интрузивно-анатектические субщелочные калиево-натриевые высокоглиноземистые граниты [14]. Обязательно существование в гранитах мелких ксенолитов карбонатных пород, по составу отвечающих доломитам. В зонах контактов гранитов и доломитов в результате процессов среднетемпературного магнезиального скарнирования формируется метасоматическая колонка следующего строения: биотитовый гранит - околоскарновый граносиенит - пироксен-амфибол клиноцоизитовый метасоматит - нефритсодержащий аподоломитовый скарн, содержащий форстерит - доломитовый мрамор. Иногда на месте гранитов могут существовать различные по составу алюмосиликатные породы. В этих случаях в составе скарнов преобладают эпидот и хлорит. Нефритсодержащие аподоломитовые скарны представляют собой жилообразные залежи [15], которые образуются под воздействием гидротермальных растворов, вызывающих тремолитизацию доломита, образование форстерит-кальцит-диопсидового скарна, а затем образование нефрита и окварцевание, вплоть до образования мономинеральных кварцевых жил.

\section{Оспинское месторождение}

Нефритовая жила Оспинского месторождения расположена на контакте родингитов и микроантигоритовых серпентинитов. Дальний от нефритовой жилы эндоконтакт родингита (табл. 2) сложен диопсидом и тремолитом, секущимися тонкими прожилками кварца и карбоната. Минеральный состав родингита по мере приближения к жиле изменяется от диопсидклиноцоизитового с прожилками полевого шпата до диопсид-клиноцоизитового родингита с прожилками кварца. Содержание титана, алюминия, магния возрастает, а кальция - уменьшается. Под родингитом обычно подразумевается ассоциация диопсида, граната, везувиана, волластонита, альбита и развитых по ним хлорита, кальцита и пренита [16]. Состав тремолититов, отделяющих нефрит от серпентинитов, зависит от их местоположения. Вблизи контакта они содержат большие количества кальция, титана, алюминия, и меньшие магния.

Зоной апосерпентинитовых месторождений нефрита являются контакты тектонически ослабленных участков серпентинизированных гипербазитов хризотил-лизардитового состава с метаморфизованными телами основных или кислых пород, где в результате инфильтрационно-диффузноного кальциевого метасоматоза образуются нефритовые жилы с повышенными концентрациями стронция, бария, цинка и титана элементов, нехарактерных для гипербазитов.

Главными особенностями Восточно-Саянского нефритоносного района является то, что месторождения апосерпентинитового нефрита формируются в гипербазитовых массивах дунит-гарцбургитовой формации [17]. Нефритовые жилы на месторождени- 
ях залегают в пределах зон, сложенных катаклазированными хризотилсодержащими серпентинитами на контакте с родингитизированными базитами и тремолитизированными плагиогранитами. Метасоматическая зональность выглядит следующим образом: микроантигоритовый серпентинит - тремолитит - нефрит - тремолитит - кварц-диопсид-клиноцоизитовый родингит цоизит-амфиболовая порода (рис. 2). Присутствие хлорита, гроссуляра, везувиана, кальцита в алюмосиликатных метасоматитах указывает на развитие процессов диафтореза, в результате которого спутанноволокнистый тремолит нефрита замещается агрегатом призматического тремолита, тальком и хлоритом. Следовательно, если метасоматический процесс не закончился, то нефритовые жилы элиминируются.

Таблица 2. Минеральный состав нефритсодержащих метасоматических колонок Оспиского месторождения Table 2. Mineral composition of jade metasomatic columns of Ospinskoe deposite

\begin{tabular}{|c|c|c|c|c|}
\hline \multirow{25}{*}{ 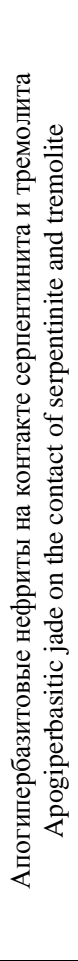 } & Порода/Rock & Минеральные асс & ции/Mineral as & ciations \\
\hline & \multirow{3}{*}{$\begin{array}{l}\text { Серпентинит } \\
\text { Serpentinite }\end{array}$} & Антигорит/Antigorite & \multicolumn{2}{|c|}{$\mathrm{Mg}_{6} \mathrm{Si}_{4} \mathrm{O}_{10} \mathrm{OH}_{8}$} \\
\hline & & Хромит/Lame & \multicolumn{2}{|c|}{$\mathrm{FeCr}_{2} \mathrm{O}_{4}$} \\
\hline & & Тальк/Talc & \multicolumn{2}{|c|}{$\mathrm{Mg}_{3} \mathrm{Si}_{4} \mathrm{O}_{10} \mathrm{OH}_{2}$} \\
\hline & \multirow{5}{*}{$\begin{array}{l}\text { Родингит (start) } \\
\text { Rodingite }\end{array}$} & Диопсид/Diopside & \multicolumn{2}{|c|}{$\mathrm{CaMgSi}_{2} \mathrm{O}_{6}$} \\
\hline & & Тремолит/Tremolite & \multicolumn{2}{|c|}{$\mathrm{Ca}_{2} \mathrm{Mg}_{5} \mathrm{Si}_{8} \mathrm{O}_{22} \mathrm{OH}_{2}$} \\
\hline & & Цоизит/Zoisite & \multicolumn{2}{|c|}{$\mathrm{Ca}_{2} \mathrm{Al}_{3} \mathrm{Si}_{3} \mathrm{O}_{12} \mathrm{OH}$} \\
\hline & & Эпидот/Epidote & \multicolumn{2}{|c|}{$\mathrm{Ca}_{2} \mathrm{FeAl}_{2} \mathrm{Si}_{3} \mathrm{O}_{12} \mathrm{OH}$} \\
\hline & & Магнетит/Magnetite & \multicolumn{2}{|c|}{$\mathrm{Fe}_{3} \mathrm{O}_{4}$} \\
\hline & \multirow{2}{*}{$\begin{array}{c}\text { Нефрит } \\
\text { Nephritis } \\
\end{array}$} & Тремолит/Tremolite & \multicolumn{2}{|c|}{$\mathrm{Ca}_{2} \mathrm{Mg}_{5} \mathrm{Si}_{8} \mathrm{O}_{22} \mathrm{OH}_{2}$} \\
\hline & & Магнетит/Magnetite & \multicolumn{2}{|c|}{$\mathrm{Fe}_{3} \mathrm{O}_{4}$} \\
\hline & \multirow{5}{*}{$\begin{array}{l}\text { Родингит (finish) } \\
\text { Rodingite }\end{array}$} & Кварц/Quartz & \multicolumn{2}{|c|}{$\mathrm{SiO}_{2}$} \\
\hline & & Тремолит/Tremolite & \multicolumn{2}{|c|}{$\mathrm{Ca}_{2} \mathrm{Mg}_{5} \mathrm{Si}_{8} \mathrm{O}_{22} \mathrm{OH}_{2}$} \\
\hline & & Цоизит/Zoisite & \multicolumn{2}{|c|}{$\mathrm{Ca}_{2} \mathrm{Al}_{3} \mathrm{Si}_{3} \mathrm{O}_{12} \mathrm{OH}$} \\
\hline & & Эпидот/Epidote & \multicolumn{2}{|c|}{$\mathrm{Ca}_{2} \mathrm{FeAl}_{2} \mathrm{Si}_{3} \mathrm{O}_{12} \mathrm{OH}$} \\
\hline & & Актинолит/Actinolite & \multicolumn{2}{|c|}{$\mathrm{Ca}_{2} \mathrm{Mg}_{5} \mathrm{Fe}_{5} \mathrm{OH}_{2}$} \\
\hline & \multirow{9}{*}{$\begin{array}{c}\text { Серицит-кварц-карбонатный сланец } \\
\text { Sericite-Quartz-Carbonate Slate }\end{array}$} & Кварц/Quartz & \multicolumn{2}{|c|}{$\mathrm{SiO}_{2}$} \\
\hline & & Биотит/Biotite & \multicolumn{2}{|c|}{$\mathrm{KMg}_{3} \mathrm{Fe}_{3} \mathrm{AlSi}_{3} \mathrm{O}_{10} \mathrm{OH}_{2} \mathrm{~F}_{2}$} \\
\hline & & Серицит/Sericite & \multicolumn{2}{|c|}{$\mathrm{KAl}_{3} \mathrm{Si}_{3} \mathrm{O}_{10} \mathrm{OH}_{2}$} \\
\hline & & Хлорит/Chlorite & \multicolumn{2}{|c|}{$\mathrm{Mg}_{6} \mathrm{Fe}_{6} \mathrm{Al}_{4} \mathrm{Si}_{4} \mathrm{O}_{10} \mathrm{OH}_{8}$} \\
\hline & & Цоизит/Zoisite & \multicolumn{2}{|c|}{$\mathrm{Ca}_{2} \mathrm{Al}_{3} \mathrm{Si}_{3} \mathrm{O}_{12} \mathrm{OH}$} \\
\hline & & Актинолит/Actinolite & \multicolumn{2}{|c|}{$\mathrm{Ca}_{2} \mathrm{Mg}_{5} \mathrm{Fe}_{5} \mathrm{OH}_{2}$} \\
\hline & & Магнетит/Magnetite & \multicolumn{2}{|c|}{$\mathrm{Fe}_{3} \mathrm{O}_{4}$} \\
\hline & & Сфен/Sphen & \multicolumn{2}{|c|}{$\mathrm{CaTiSiO}_{5}$} \\
\hline & & Полевой шпат/Feldspar & $\begin{array}{c}\text { Микроклин } \\
\text { Мicrocline } \\
\text { Андезин } \\
\text { Andesine }\end{array}$ & $\begin{array}{c}\mathrm{KAlSi}_{3} \mathrm{O}_{8} \\
\mathrm{NaCaSiAl}_{4} \mathrm{O}_{8}\end{array}$ \\
\hline
\end{tabular}

Контакты апосерпентинитовых нефритовых жил с родингитами фиксируют существовавшую ранее границу серпентинитов с алюмосиликатными породами. Тремолит, присутствовавший в родингитах, не образует харак-

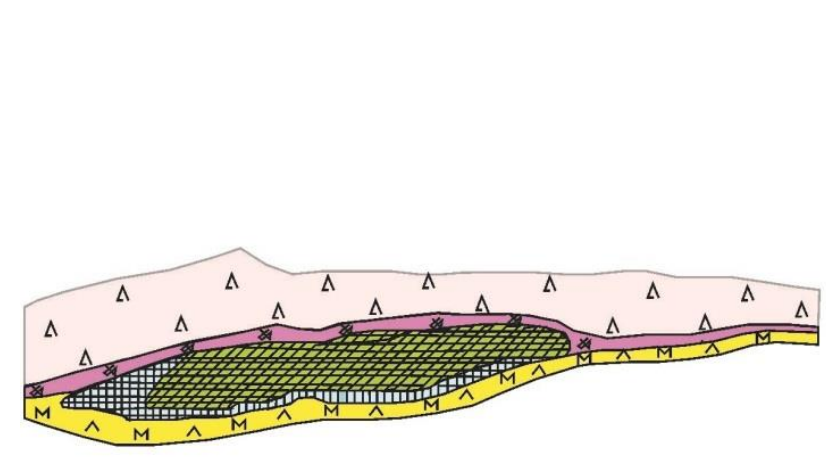

терной для нефритов спутанно-волокнистой структуры. Это продукты Fe-Mg-Са метасоматоза, поэтому новообразованные минералы независимо от состава замещаемой породы имеют алюмо-кальциево-силикатный состав.

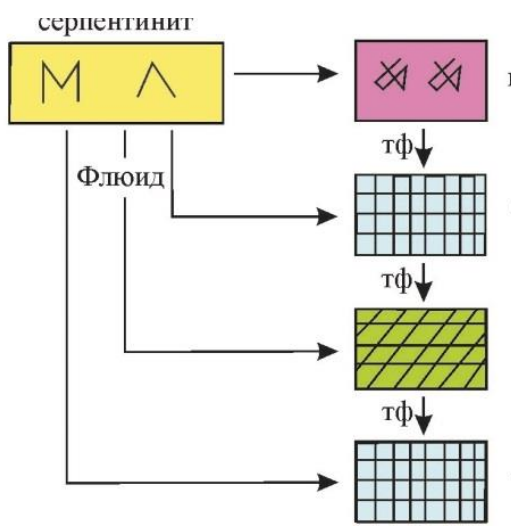

кварцклиноцоизитовый родингит тремолит нефрит тремолит

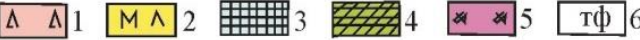

Рис. 2. Схема нефритовой жиль на контакте апогипербазитовых родингитов с серпентинитами и блок-схема последовательных стадий образования нефрита [5]: 1 - гранитизированное габбро; 2 - серпентиниты; 3 тремолит; 4 - нефриты; 5 - квари-клиноиоизит-диопсидовые родингиты; 6-твердые фазы

Fig. 2. Scheme of the jade vein on contact of apohyperbasite rodigites with serpentinites and flowchart of linear stages of jade formation [5]: 1 - granite gabbro; 2 - serpentines; 3 -tremolite; 4 - jades; 5 - quarz-clinozoisite-diopside rodingites; 6 - solids 


\section{Генетические проблемы нефритообразования}

В глобальных процессах гидратации и метасоматоза гипербазитов нефритообразование занимает определенное место. Тела нефритов приурочены к массивам гипербазитов с магнезиальным составом. Метасоматическая зональность может быть нескольких типов. Общим для всех типов зональности вне зависимости от состава алюмосиликатных пород является наличие серпентинита и оталькование пород. Состав алюмосиликатных метасоматитов зависит от состава исходной породы, но парагенезисы тыловых $30 н$ всегда включают диопсид и цоизит. Единообразие зональности метасоматитов обусловлено воздействием флюидов близкого состава [18].

Нефритовые парагенезисы формируются в Р-T условиях зеленосланцевой фации метаморфизма. О восстановленном характере флюидного режима свидетельствует преобладание в нефритах закисного железа, сульфидов никеля и графита. В анионной части флюидов предполагается присутствие хлора, фиксируемое в составе апосерпентинитовых нефритов, и фтора в случае апокарбонатных нефритов.

Нефрит - это типичная контактовая порода, формирующаяся в результате метасоматического замещения серпентинитов или других ультраосновных пород [1]. Термальные растворы, проникавшие в зону контакта, серпентинизировали исходные породы и образовывали нефритовые жилы.

В процессе замещения серпентинита нефритовым агрегатом сохраняется рисунок вкрапленности хромшпинелида и тонковолокнистого тремолита по карбонату. Амфибол-цоизитовые породы преобразуются в родингиты, сложенные кварцем, клиноцоизитом и диопсидом. С термальными растворами в серпентиниты привносится кальций и кремний, магний выносится, а алюминий и железо инертны. В процессах образования апокарбонатных нефритов мрамора за счет поступления кремния, алюминия, калия, и магния, а также удаления $\mathrm{CO}_{2}$ и кальция серпентинизируются.

Призматические тремолиты замещают нефрит в условиях длительного воздействия гидротерм, приводящего к перекристаллизации волокон в призмы при тех же химических составах флюидов, но иных Р-T условиях. Появление хлорита в нефритах служит индикатором ухудшения качества нефрита [19].

\section{Физико-химические модели нефритообразования}

Модель всегда отличается от своего реального воплощения. Она задает принципиальные границы процесса, определяет его вектор и те компоненты, существование которых вероятно. На каждой более или менее завершенной стадии вводятся корректирующие поправки. Создать универсальную модель формирования и развития флюидных систем невозможно, но возможно разработать количественные схемы эволюции базовых структурно-динамических типов флюидных и магматических систем с моделями тех процессов, которые управляют растворением, переносом и отложением микро- и макроэлементов. Такой подход позволит выделить стандартную часть, которую можно рассмотреть с помощью готовых алгоритмов, вычислительных схем и программ, и нестандартную, связанную со спецификой данного геологического объекта, что позволит реконструировать как общий характер, так и особенности эволюции конкретной флюидной системы.

Вместе с качественными геолого-геохимическими построениями и аналитическими данными имитационное моделирование единственно пригодное средством исследования особенностей флюидных систем. Даже в сравнительно простых моделях с участием флюидных растворов приходится значительно увеличивать количество индивидуальных веществ в мультисистеме. Список веществ, потенциально возможных в равновесии, становится более обширным, если одновременно с водным раствором присутствует и газовая смесь. Именно динамическое изменение баланса водный раствор - газовая смесь - один из главных факторов гидротермальных процессов.

На первой стадии формирования модели необходимо подобрать химические элементы, полноценно описывающие состав системы [20]. Исключение того или иного элемента может сократить набор возможных минералов, нарушив последовательность их кристаллизации. Обязательны как макро-, так и микроэлементы, контролирующие физико-химические параметры нефритообразования [21]. Макроэлементы определяют «кислотность-щелочность» флюидов и окислительно-восстановительный потенциал процесса минералообразования и фазовый состав. Микроэлементы влияют на второстепенные свойства минералов - цвет, прозрачность [22]. В определенных Р-Т условиях некоторые из этих элементов могут образовывать собственные фазы, содержания которых меньше, чем $10^{-6}$ моль. Выбор микроэлементов для каждой геохимической системы производится исходя из роли элементов в изучаемом процессе и наличия термодинамических свойств их соединений.

На основе химического состава различных метасоматических зон [22] установлен набор элементов, достаточный для формирования физико-химических моделей процесса образования нефрита (табл. 5). Это калий и натрий, роль которых в амфиболообразовании доказана экспериментально; кальций и магний, кремний, алюминий и железо, содержание которых контрастно в метасоматических зонах. Хром и никель определяют хромофорные характеристики. Обнаружение сульфидов никеля предопределило включение серы в физико-химическую модель. Также в нефритах присутствуют титан, фосфор, марганец, наследуемые из замещающих пород. Хлор, фтор, углерод, кислород, водород включены как значимые компоненты нефритообразующих флюидов.

Выбор возможных водных, газообразных соединений и твердых фаз определяется списком химических элементов, включенных в модель. В растворах должны присутствовать простые ионы, окислы, гидроокислы, карбонаты, хлориды, фториды и сульфиды. Обязательно включение водорастворимых газов и самих газов. Необходимо задать твердые растворы основных минералов, индивидуальных соединений, и 
собственных фаз микроэлементов, существование которых возможно в Р-Т условиях метасоматических процессов. Список основных, наиболее вероятных компонентов, включенных в физико-химическую модель, представлен в табл. 5.

Стабильность нефритовых парагенезисов в условиях зеленокаменной фации метаморфизма указывает на то, что моделирование следует проводить в границах 2-3 кбар. Эксперименты по синтезу тремолитасбеста проводились при температурах в $400-500{ }^{\circ} \mathrm{C}$. Следовательно, оптимальный температурный интервал моделирования $300-450{ }^{\circ} \mathrm{C}$. Особенности химического и редкоэлементного состава вмещающих нефритовые жилы породы изученной области подробно рассмотрены в публикациях М.С. Холькина [23]. Их средние химические составы приведены в табл. 3,4 .

Таблица 3. Химический состав метасоматитов жиль 6 Оспинского месторождения (вес. \%)

Table 3. Chemical composition of metasomatites of vein 6 of Ospinskoe deposite (wt. \%)

\begin{tabular}{|c|c|c|c|c|c|}
\hline 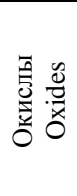 & 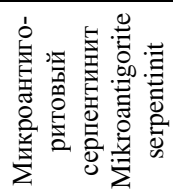 & 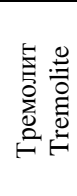 & 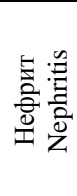 & 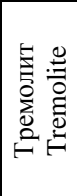 & 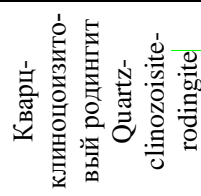 \\
\hline $\mathrm{SiO}_{2}$ & 42,42 & 56,65 & 55,72 & 54,91 & 51,12 \\
\hline $\mathrm{TiO}_{2}$ & 0,04 & & & 0,02 & 0,51 \\
\hline $\mathrm{Al}_{2} \mathrm{O}_{3}$ & 0,81 & 0,27 & 1,44 & 1,97 & 6,10 \\
\hline $\mathrm{Fe}_{2} \mathrm{O}_{3}$ & 2,77 & 1,20 & 1,18 & 1,15 & 1,90 \\
\hline $\mathrm{FeO}$ & 3,95 & 1,98 & 2,33 & 2,87 & 2,87 \\
\hline $\mathrm{MnO}$ & 0,13 & 0,09 & 0,10 & 0,08 & 0,15 \\
\hline $\mathrm{CaO}$ & 0,56 & 11,76 & 12,18 & 11,76 & 19,60 \\
\hline $\mathrm{MgO}$ & 36,59 & 24,90 & 24,19 & 22,88 & 15,42 \\
\hline $\mathrm{K}_{2} \mathrm{O}$ & 0,01 & 0,01 & 0,03 & 0,06 & 0,06 \\
\hline $\mathrm{Na}_{2} \mathrm{O}$ & 0,001 & 0,001 & 0,04 & 0,04 & 0,17 \\
\hline $\mathrm{P}_{2} \mathrm{O}_{5}$ & - & - & - & - & 0,34 \\
\hline
\end{tabular}

Таблица 4. Химический состав пород Кавоктинского месторождения, (вес. \%)

Table 4. Chemical composition of rocks of Kavoktinskoe deposit (wt. \%)

\begin{tabular}{|c|c|c|c|c|c|c|c|}
\hline 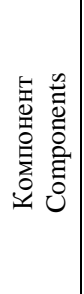 & 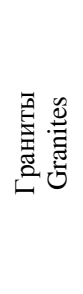 & 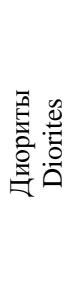 & 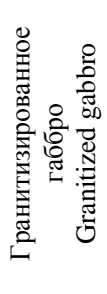 & 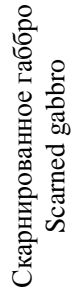 & 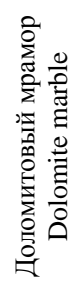 & 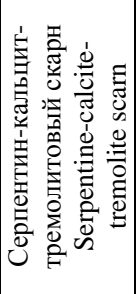 & 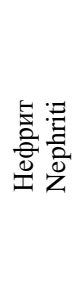 \\
\hline $\mathrm{SiO}_{2}$ & 71,65 & 62,8 & 48,50 & & 2,50 & 52,3 & 54,8 \\
\hline $\mathrm{TiO}_{2}$ & 0,37 & 0,69 & 1,7 & 0,79 & 0,13 & 0,05 & 0,05 \\
\hline $\mathrm{A} 1_{2} \mathrm{O}_{3}$ & 13,37 &, 52 & 16,06 & 15,84 & 1,01 & 3,03 & 2,76 \\
\hline $\mathrm{Fe}_{2} \mathrm{O}_{3}$ & 0,61 & 1,23 & 4,41 & 5,72 & 0,02 & 0,95 & 0,77 \\
\hline $\mathrm{FeO}$ & 2,20 & 2,9 & 6,77 & 4,10 & 0,11 & 0,35 & 0,75 \\
\hline $\mathrm{MnO}$ & 0,04 & 0,04 & 0,14 & 0,16 & & 0,14 & 0,1 \\
\hline $\mathrm{CaO}$ & 2,73 & 3,0 & 8,86 & 16,03 & 29,79 & 18,82 & 11,89 \\
\hline $\mathrm{MgO}$ & 1,33 & 1,72 & 6,17 & 8,15 & 20,53 & 19,59 & 23,42 \\
\hline $\mathrm{K}_{2} \mathrm{O}$ & 2,54 & 2,7 & 1,9 & 0,35 & 0,02 & 0,23 & 0,1 \\
\hline $\mathrm{Na}_{2} \mathrm{O}$ & 3,05 & 3,6 & 2,04 & 1,7 & 0,05 & 0,17 & 0,14 \\
\hline $\mathrm{P}_{2} \mathrm{O}_{5}$ & 0,06 & 0,24 & 0,57 & 0,84 & 0,01 & 0,17 & 0,06 \\
\hline & & & 0,2 & & & & \\
\hline
\end{tabular}

Таким образом, выполнен важный этап подготовки физико-химической модели. Подобраны химические и минеральные составы нефритовой жилы на контакте апогипербазитовых родингитов с серпентинитами и нефритовой жилы на контакте доломитовых мраморов с метаморфизованными гранитами. Определены температуры и давления процесса, известен источник водного флюида и состав растворенных газов. Разработана рабочая блок-схема процесса и по ней подготовлена многорезервуарная физикохимическая модель.

В отличии от предшествующих работ впервые будут определены составы флюидов и интенсивность метасоматического процесса, то есть дана количественная оценка массопереноса. Это позволит численно оценить влияние летучих компонентов на метасоматическую зональность. Также будут определены масштабы изменения Еh и $\mathrm{pH}$ растворов на завершающих стадиях метасоматического процесса [24]. Подготовленные физико-химические модели процесса нефритообразования будут надежно подтверждены полевыми исследованиями.

Таблица 5. Основные компоненты физико-химической модели

Table 5. Major components of the physico-chemical model Независимые компоненты/Independent components

$\mathrm{Si}, \mathrm{Al}, \mathrm{Fe}, \mathrm{Ca}, \mathrm{Mg}, \mathrm{K}, \mathrm{Na}, \mathrm{Mn}, \mathrm{Cl}, \mathrm{F}, \mathrm{S} . \mathrm{C}, \mathrm{O}$,

e (электрон/electron)

Компоненты флюида/Fluid components

$\mathrm{Al}(\mathrm{OH})_{2}{ }^{+}, \mathrm{Al}(\mathrm{OH})_{3}{ }^{0}, \mathrm{Al}(\mathrm{OH})_{4}{ }^{-}, \mathrm{Al}^{3+}, \mathrm{AlSO}_{4}{ }^{+}, \mathrm{F}^{-}, \mathrm{HF}^{0}, \mathrm{CH}_{4}{ }^{0}$

$\mathrm{CO}^{0}, \mathrm{CO}_{2}{ }^{0}, \mathrm{Cl}^{-}, \mathrm{H}_{2} \mathrm{O}, \mathrm{N}_{2} \mathrm{O}, \mathrm{NH}_{3}{ }^{0}, \mathrm{NH}_{4}^{+}, \mathrm{NO}_{3}^{-}, \mathrm{O}_{2}{ }^{0}, \mathrm{~S}_{2}^{-}, \mathrm{SO}_{4}{ }^{2-}$ $\mathrm{CO}^{3-}, \mathrm{Fe}(\mathrm{OH})_{2}{ }^{+}, \mathrm{Fe}(\mathrm{OH})_{3}{ }^{0}, \mathrm{Fe}(\mathrm{OH})^{3-}, \mathrm{Fe}^{2+}, \mathrm{Fe}^{3+}, \mathrm{FeCl}^{+}, \mathrm{FeCl}_{2}{ }^{0}$, $\mathrm{FeCl}^{2+}, \mathrm{FeHS}^{+}, \mathrm{FeSO}_{4}{ }^{0}, \mathrm{FeSO}_{4}{ }^{+}, \mathrm{Ca}\left(\mathrm{CO}_{3}\right)^{2-}, \mathrm{Ca}(\mathrm{OH})_{2}{ }^{0}, \mathrm{Ca}^{2+}$, $\mathrm{CaCO}_{3}^{0}, \mathrm{CaCl}_{2}{ }^{0}, \mathrm{CaOH}^{+}, \mathrm{CaSO}_{4}^{0}, \mathrm{H}_{2} \mathrm{SO}_{2} \mathrm{H}_{2} \mathrm{SO}_{4}^{0}, \mathrm{HS}^{-}, \mathrm{HSO}^{4-}$ $\mathrm{H}_{2} \mathrm{SiO}^{4-}, \mathrm{H}_{3} \mathrm{SiO}^{3+}, \mathrm{H}_{3} \mathrm{SiO}^{4}, \mathrm{HCO}^{3-}, \mathrm{HCl}^{0}, \mathrm{HNO}_{3}{ }^{0}, \mathrm{H}_{2} \mathrm{CO}_{3}{ }^{0}, \mathrm{~K}^{+}$, $\mathrm{K}_{2} \mathrm{CO}_{3}{ }^{0}, \mathrm{~K}_{2} \mathrm{SO}_{4}{ }^{0}, \mathrm{KCO}^{3-}, \mathrm{KCl}^{0}, \mathrm{KOH}^{0}, \mathrm{KSO}^{4-}, \mathrm{Mg}(\mathrm{OH})_{2}{ }^{0}, \mathrm{Mg}^{2+}$ $\mathrm{MgCO}_{3}{ }^{0}, \mathrm{MgCl}_{2}{ }^{0}, \mathrm{MgOH}^{+}, \mathrm{MgSO}_{4}{ }^{0}, \mathrm{Mn}^{2+}, \mathrm{MnOH}^{+}, \mathrm{Na}^{+}$, $\mathrm{Na}_{2} \mathrm{CO}_{3}{ }^{0}, \mathrm{Na}_{2} \mathrm{SO}_{4}{ }^{0}, \mathrm{NaCO}^{3-}, \mathrm{NaCl}^{0}, \mathrm{NaSO}_{4}^{-}, \mathrm{OH}^{-}, \mathrm{H}^{+}, \mathrm{H}_{2} \mathrm{O}$ Газы/Gases

$\mathrm{Cl}_{2}, \mathrm{~F}_{2}, \mathrm{HCl}, \mathrm{H}_{2}, \mathrm{H}_{2} \mathrm{~S}, \mathrm{H}_{3} \mathrm{~N}, \mathrm{NO}, \mathrm{NO}_{2}, \mathrm{~N}_{2}, \mathrm{~N}_{2} \mathrm{O}, \mathrm{O}_{2}, \mathrm{CO}, \mathrm{CO}_{2}$, $\mathrm{CH}_{4}, \mathrm{C}_{2} \mathrm{H}_{6}, \mathrm{C}_{3} \mathrm{H}_{8}$

\section{Твердые фазы/Solid phases}

Кварц, биотит, магнетит, сфен, тремолит, антигорит, тальк, хромшпинелид, цоизит, хлорит, микроклин, санидин, лейкоксен, кальцит, доломит, форстерит, роговая обманка, андезин, олигоклаз, апатит, ортоклаз, адуляр, анортит, альбит, серпентин, нефрит, диопсид, актинолит, серицит.

Quartz, biotite, magnetite, sphene, tremolite, antigorite, talc, chrome spinelide, zoisite, chlorite, microcline, sanidin,

leucoxene, calcite, dolomite hornblende, andesine, oligoclase, apatite, orthoclase, adular, anorthite, albite, serpentine, nephrite, diopside, actinolite, sericite

\section{Заключение}

Подготовлены исходные данные для двух физикохимических моделей образования нефрита - апокарбонатного и апогипербазитового. Определены вероятные минеральные парагенезисы в метасоматических зональностях и особенности компонентного состава гидротермальных растворов для этих типов месторождений. Физико-химическое моделирование позволит точно определить соотношение масс взаимодействующих пород, необходимое количество флюида и относительное время его взаимодействия, 
предсказать, что произойдет с нефритовой жилой, если метасоматоз будут растянут во времени. Следовательно, по известной метасоматической зональности можно будет реконструировать относительный возраст месторождения, массы перемещенных веществ и установить роль глубинных (эндогенных) источников летучих компонентов, а также определить, почему, несмотря на широкую распространенность и протяженность контактов гипербазитов и габбро, гранитов и доломитов, месторождения нефритов относительно редки, малоразмерны и уникальны по химическому составу.

Одной из причин образования нефритсодержащих тел является строго определенное соотношение масс взаимодействующих пород и то обстоятельство, что источник тепла может не являться источником флюида. Общее количество флюида, которое может пройти через зону контакта, позволяет определить относительное время метасоматического процесса. Главным

\section{СПИСОК ЛИТЕРАТУРЫ}

1. Нефриты Восточной Сибири: геохимические особенности и проблемы генезиса / М.В. Бурцева, Г.С. Рипп, В.Ф. Посохов, А.Е. Мурзинцева // Геология и геофизика. 2015. - Т. 56. № 3. - C. 516-527.

2. Vennemann T.W., O'Neil J.R. A simple and inexpensive method of hydro-gen isotope and water analyses of miner-als and rocks based on zinc reagent // Chemical Geology. - 1993. - V. 103. P. 227-234.

3. Источники флюидов, формировавших апогипербазитовые метасоматиты западного Забайкалья / М.В. Рампилова, Г.С. Рипп, Б.Б. Дамдинов, М.О. Рампилов, В.Ф. Посохов // Геология, поиски и разведка месторождений полезных ископаемых. 2017. - T. 40. - № 2. - C. 23-35.

4. Halperin C.T., Hruby Z.X., Mongelluzzo R. The weight of ritual: classic Maya jade head pendants in the round // Antiquity. 2018. - V. 92. - P. 758-771

5. Сутурин А.Н., Замалетдинов Р.С., Секерина Н.В. Месторождения нефрита. -Иркутск: Изд-во ИГУ, 2015. - 377 с.

6. Медведев В.Я., Иванова Л.А. Флюидный режим нефритообразования. - Новосибирск: Изд-во Наука, Сиб. отд-ние, 1989. $129 \mathrm{c}$.

7. Карпов И.К., Чудненко К.В., Сутурин А.Н. Мегасистема контактово-инфильтрационного метасоматоза и ее расчет на ЭВМ // Геология и геофизика. - 1987. - № 11. - С. 57-64.

8. Гомбоев Д.М., Андросов П.В., Кислов Е.В. Кавоктинское месторождение светлоокрашенного нефрита: условия залегания и особенности вещественного состава // Разведка и охрана недр. - 2017. - № 9. - С. 44-50

9. Composition and distinction of white nephrite from Asian deposits / L. Xiaoxiao, S. Esther, W. Ruihua, W. Shiqi, G. Jürgen // Journal of Mineralogy and Geochemistry. - 2013. - V. 190. - P. 49-65.

10. A method of determining heated ancient nephrite jades in China / Y. Bao, C. Zhao, Y. Li, X. Yun // Scientific reports. - 2018. P. 1-11.

11. Секерина Н.В. Условия локализации месторождений апокарбонатного нефрита средне-Витимской горной страны // Геология и геофизика. - 1988. - № 11. - С. 106-111.

12. Кочнев А.П., Краснов Д.А. Факторы нефритоносности Голюбинско-Олламинского нефритоносного поля (Республика Бурятия) // Известия Сибирского отделения секции наук о Земле Российской академии естественных наук. Геология, разведка и разработка месторождений полезных ископаемых. - 2017. T. 40. - № 1. - C. 52-65.

13. Кочнев А.П., Краснов Д.А., Иванова Р.Н. Опыт многофакторного локального прогнозирования на примере голюбинскоолламинского нефритоносного поля (республика Бурятия) // Известия Сибирского отделения Секции наук о Земле РАЕН. фактором, контролирующим образование спутанноволокнистой структуры тремолитов, является шоковое увеличение давления в скарнах за счет серпентинизации. Вероятно, поэтому в родингитах, где температура ниже, а давление не испытывает резких изменений, тремолит не образует характерной для нефритов спутанно-волокнистой структуры. Это предположение будет проверено моделированием процесса формирования нефритсодержащих скарнов с ограничением на объем. Согласно представлениям И.К. Карпова, разработчика программного комплекса «Селектор»: «Особое внимание следует уделять проблеме достоверности эмпирических обобщений, которые будут приняты в качестве физико-химических законов эволюции метасоматитов, поскольку возможности построения концептуальных теорий их формирования ограничены точностью геолого-геохимической информации» [7].

Геология, разведка и разработка месторождений полезных ископаемых. - 2018. - Т. 41. - № 4. - С. 50-66.

14. Glow discharge mass spectrometry studies on nephrite minerals formed by different metallogenic mechanisms and geological environments / B. Siqin, R. Qian, S.J. Zhuo, F.X. Gan, M. Dong, Y.F. Hua // International Journal of Mass Spectrometry. - 2012. V. 309. - P. 206-211.

15. Секерин А.П. О роли разрывных нарушений в формировании нефритовых месторождений Средне-Витимской горной страны // Разломы и эндогенное оруденение Байкало-Амурского региона. - М.: Изд-во «Наука», 1982. - С. 116-121.

16. Коржинский А.Ф. Скарновые образования в ОспинскоКитойском гипербазитовом массиве в Восточном Саяне // Записки Всесоюзного минералогического общества. 1958. T. 87. - № 3. - С. 327-347.

17. Колесник Ю.Н. Нефриты Сибири. - Новосибирск: Изд-во «Наука», Сиб. отд-ние, 1965. - 150 с.

18. Kovacevich B., Callaghan M.G. Fifty shades of green: interpreting Maya jade production, circulation, consumption, and value // Ancient Mesoamerica. - 2018. - V. 30. - P. 457-472.

19. Сутурин А.Н., Замалетдинов Р.С., Гаврилова В.П. Геохимические и геофизические методы поисков месторождений нефрита // Геохимические поиски самоцветов. - Новосибирск: Наука, Сиб. отд-ние, 1990. - С. 45-76.

20. Сутурин А.Н. Методические вопросы моделирования метасоматических процессов (на примере нефритообразования) // Физико-химические модели в геохимии. - Новосибирск: Наука, Сиб. отд-ние, 1988. - С. 4-37.

21. Formation of Au-bearing antigorite serpentinites and magnetite ores at the massif of ophiolite ultramafic rocks: thermodynamic modeling / V. Murzin, K. Chudnenko, G. Palyanova, D. Varlamov // Minerals. - 2019. - V. 9. - P. 758-782.

22. Physicochemical models of formation of gold-silver ore mineralization at the Rogovik deposit (Northeastern Russia) / T.V. Zhuravkova, G.A. Palyanova, K.V. Chudnenko, R.G. Kravtsova, I.R. Prokopyev, A.S. Makshakov, A.S. Borisenko // Ore Geology Reviews. -2017. - V. 91. - P. 1-20.

23. Холькин М.С. Особенности состава и генезиса нефритов Саяно-Байкальской горной области // Проблемы геологии и освоения недр: Труды IX Международного научного симпозиума имени академика М.А. Усова студентов и молодых ученых. Томск: Изд-во Томского политехнического университета, 2005. - C. 16-18.

24. Harlow G.E., Sisson V.B., Sorensen S.S. Jadeitite from Guatemala: new observations and distinctions among multiple occurrences // Geologica Acta. - 2011. - V. 9. - P. 363-387.

Поступила: 19.06.2020 2. 
Информация об аторах

Филиппова A.A., аспирант, инженер-исследователь Института геохимии им. А.П. Виноградова СО РАН.

Мехоношин A.C., кандидат геолого-минералогических наук, старший научный сотрудник Института геохимии им. А.П. Виноградова; профессор Иркутского национального исследовательского технического университета.

Бычинский B.A., кандидат геолого-минералогических наук, старший научный сотрудник Института геохимии им. А.П. Виноградова.

Чудненко К.В., доктор геолого-минералогических наук, ведущий научный сотрудник Института геохимии им. А.П. Виноградова. 
UDC 553.8550 .42

\title{
PHYSICO-CHEMICAL FEATURES OF FLUIDES, WHICH FORMED APOHYPERBASITE, AND APOCARBONATE JADES
}

\author{
Anastasia A. Filippova1, \\ a.filippova@igc.irk.ru
}

\author{
Alexey S. Mekhonoshin 1,2, \\ mekhonos@igc.irk.ru
}

Valery A. Bychinsky', val@igc.irk.ru

\author{
Konstantin V. Chudnenko', \\ chud@igc.irk.ru \\ 1 A.P. Vinogradov Institute of Geochemistry SB RAS, \\ 1A, Favorsky street, P.O. box 9, Irkutsk, 664033, Russia. \\ 2 Irkutsk National Research Technical University, \\ 83, Lermontov street, Irkutsk, 664074, Russia.
}

The relevance. The deposits of two formation types (apohyperbasire and apocarbonate) were discovered in the jade province of Siberia, the largest in Russia. Their bodies are usually formed on the contact of serpentinized rocks and dolomite marbles with the aluminisilicate rocks. It is necessary to identify the genetic differences in jade of various formational accessories that allows making a conclusion on the sources of the fluid phase and answering the actual question about the oxygen source in the minerals forming the jade.

The main aim of the research is to justify the physiochemical conditions of jade formation with the help of a critical summary of the world's material on the geochemistry and petrology of jade.

Objects: Kavoktinskoe deposit of apocarbonate jade and Osipinskoe deposite of apohyperbasite jade.

Methods. Chemical composition of the rocks was determined by photometric, atomic absorption, potentiometric and flame photometric methods. Trace element analysis was done by inductively coupled plasma mass spectrometry. The isotopic compositions of oxygen and carbon were analyzed by laser fluorination, and carbon and oxygen in carbonates - by the method of decomposition with orthophosphate acid. The isotopic composition of hydrogen in hydroxyl-containing minerals was determined by the method of Vennemann, O'Neil.

Results. It was found that apogiperbasitic jades were formed under the influence of magmatic and metamorphic fluids released during the deserpentization of rocks; and in apocarbonate jade occurrences, the fluid is meteoric water saturated with carbon dioxide formed during decarbonization of dolomite. The order of formation of mineral paragenesis during the expansion of metasomatic zonation on the contact of rocks of various compositions was considered. It was shown that the uniformity of the mineralogical types of jade of a various genesis depends on composition of the hydrothermal solution, and P-T conditions of the process. Apocarbonate jade belongs to the low-temperature facies of magnesian skarns by the mineral paragenesis. As a result, the following metasomatic zoning is formed: dolomite marble - calcite marble with jade - tremolite skarn - pyroxene - amphibole - clinocyoisite skarn - amphibolites. The deposits of apohyperbasite jade have the different metasomatic zonality: microantigorite serpentinite - tremolithite - jade - tremolite - quartz-diopside-clinocyosite rhodingite cyosite-amphibole rock. The temperature varies in the range of $300-450^{\circ} \mathrm{C}$, the pressure is $2000-3000$ bar. These data allow us to create a model that properly describes the characteristics of the physicochemical processes of both apocarbonate and apogiperbasitic jade formation.

\section{Key words:}

Jade, geochemistry, isotopes, physicochemical forming conditions, Eastern Siberia.

\section{REFERENCES}

1. Burtseva M.V., Ripp G.S., Posokhov V.F., Murzintseva A.E. Jades of Eastern Siberia: geochemical features and problems of the genesis. Geology and geophysics, 2015, vol. 56, no. 3. pp. 516-527. In Rus.

2. Vennemann T.W., O'Neil J.R. A simple and inexpensive method of hydro-gen isotope and water analyses of minerals and rocks based on zinc reagent. Chemical Geology, 1993, vol. 103, pp. 227-234.

3. Rampilova M.V., Ripp G.S., Damdinov B.B., Rampilov M.O., Posokhov V.F. Sources of fluids forming apogiperbasitic metasomatites of western Transbaikalia. Geology, prospecting and exploration of mineral deposits, 2017, vol. 40, no. 2, pp. 23-35. In Rus.

4. Halperin C.T., Hruby Z.X., Mongelluzzo R. The weight of ritual: classic Maya jade head pendants in the round. Antiquity, 2018, vol. 92, pp. $758-771$.

5. Suturin A.N., Zamaletdinov R.S., Sekerina N.V. Mestorozhdeniya nefrita [Jade deposits]. Irkutsk, ISU Publ., 2015. 377 p.
6. Medvedev V.Ya., Ivanova L.A. Fluidny rezhim nefritoobrazovaniya [Fluids of oil formation]. Novosibirsk, Nauka publ., Sib. Department, 1989. $129 \mathrm{p}$

7. Karpov I.K., Chudnenko K.V., Suturin A.N. The megasystem of contact-infiltration metasomatism and its computer calculation. Geology and Geophysics, 1987, no. 11, pp. 57-64. In Rus.

8. Gomboev D.M., Androsov P.V., Kislov E.V. Kavokta deposit of light-colored jade occurense and characteristics of the composition. Exploration and protection of subsurface resources, 2017, vol. 9, pp. 44-50. In Rus.

9. Xiaoxiao L., Esther S., Ruihua W., Shiqi W., Jürgen G. Composition and distinction of white nephrite from Asian deposits. Journal of Mineralogy and Geochemistry, 2013, vol. 190, pp. 49-65.

10. Bao Y., Zhao C., Li Y., Yun X. A method of determining heated ancient nephrite jades in China. Scientific reports, 2018, pp. 1-11.

11. Sekerina N.V. Localization conditions for apocarbonate jade deposits of Mid-Vitim Highlands. Geology and geophysics, 1988, no. 11, pp. 106-111. In Rus. 
12. Kochnev A.P., Krasnov D.A. Factors of nephritic GolyubinskOllaminskogo nephritic field (Republic of Buryatia). Bulletin of the Siberian Branch of the Earth Sciences Section of the Russian Academy of Natural Sciences. Geology, exploration and development of mineral deposits, 2017, vol. 40, no. 1, pp. 52-65. In Rus.

13. Kochnev A.P., Krasnov D.A., Ivanova R.N. An experience of multifactor local prognosis on the example of the GolyubinskyAllaminsky nephritic field (Republic of Buryatia). Bulletin of the Siberian Branch of the Section of Earth Sciences of Russian Academy of Natural Sciences. Geology, exploration and development of mineral deposits, 2018, vol. 41, no. 4, pp. 50-66. In Rus.

14. Siqin B., Qian R., Zhuo S.J., Gan F.X., Dong M., Hua Y.F. Glow discharge mass spectrometry studies on nephrite minerals formed by different metallogenic mechanisms and geological environments. International Journal of Mass Spectrometry, 2012, vol. 309, pp. 206-211.

15. Sekerin A.P. Razlomy $i$ endogennoe orudenenie BaikaloAmurskogo regiona [Faults and endogenous mineralization of Baikal-Amur region]. Moscow, Nauka Publ., 1982. 121 p.

16. Korzhinsky A.F. Skarnovye obrazovaniya v Ospinsko-Kitoyskom giperbazitovom massive v Vostochnom Sayane [Skarn formation on Ospinsky-Kitoysky hyperbasite massif at Eastern Sayan]. Zapiski Vsesoyuznogo mineralogicheskogo obshchestva, 1958 , no. 3, pp. 327-347.

17. Kolesnik Yu.N. Nefrity Sibiri [Nephrites of Siberia]. Novosibirsk, Nauka Publ., 1965. 150 p.

18. Kovacevich M.G., Callaghan M.G. Fifty shades of green: interpreting Maya jade production, circulation, consumption, and value. Ancient Mesoamerica, 2018, vol. 30, pp. 457-472.

19. Suturin A.N., Zamaletdinov R.S., Gavrilova V.P. Geokhimicheskie i geofizicheskie metody poiskov mestorozhdenii nefrita [Geochemical and geophysical methods of searching for jade deposits].
Geochimicheskie poiski samotsvetov [Geochemical searches for gems]. Novosibirsk, Nauka Publ., 1990. pp. 45-76.

20. Suturin A.N. Metodicheskie voprosy modelirovaniya metasomaticheskikh protsessov (na primere nefritoobrazovania) [Methodological issues of modeling metasomatic processes (on the example of oil formation)]. Fiziko-khimicheskie modeli v geokhimii [Physicochemical models in geochemistry]. Novosibirsk, Nauka Publ., 1988. pp 4-37.

21. Murzin V., Chudnenko K., Palyanova G., Varlamov D. Formation of Au-bearing antigorite serpentinites and magnetite ores on the massif of ophiolite ultramafic rocks: thermodynamic modeling. Minerals, 2019, vol. 9, pp. 758-782.

22. Zhuravkova T.V., Palyanova G.A., Chudnenko K.V., Kravtsova R.G., Prokopyev I.R., Makshakov A.S., Borisenko A.S. Physicochemical models of formation of gold-silver ore mineralization at Rogovik deposit (Northeastern Russia). Ore Geology Reviews, 2017, vol. 91, pp. 1-20.

23. Kholkin M.S. Osobennosti sostava i genezisa nefritov SayanoBaykalskoy gornoy oblasti [Characteristics of composition and genesis of jade at Sayan-Baikal mountain region]. Problemy geologii i osvoyeniya nedr. Trudy IX Mezhdunarodnogo nauchnogo simpoziuma imeni akademika M.A. Usova studentov i molodykh uchenykh [Problems of geology and recourses exploration. Proc. of the IX International Academic Symposium after academician M.A. Usov for students and young scientists]. Tomsk, Tomsk Polytechnic University Publ. house, 2005. Pp. 16-18.

24. Harlow G.E., Sisson V.B., Sorensen S.S. Jadeitite from Guatemala: new observations and distinctions among multiple occurrences. Geologica Acta, 2011, vol. 9, pp. 363-387.

Received: 19 June 2020.

\section{Information about the authors}

Anastasia A. Filippova, postgraduate student, engineer researcher, A.P. Vinogradov Institute of Geochemistry SB RAS. Alexey S. Mekhonoshin, Cand. Sc., senior researcher, A.P. Vinogradov Institute of Geochemistry SB RAS; professor, Irkutsk National Research Technical University.

Valery A. Bychinsky, Cand. Sc., senior researcher, A.P. Vinogradov Institute of Geochemistry SB RAS.

Konstantine V. Chudnenko, Dr. Sc., leading researcher, A.P. Vinogradov Institute of Geochemistry SB RAS. 